http://dx.doi.org/10.1080/2156857X.2017.1343743.

\title{
Housing Pathways, Not Belonging and Sense of Home as Described by Unaccompanied Minorsi $^{\mathrm{i}}$
}

Outi Kauko (corresponding author)

PhD student, social work

Hannele Forsberg

Professor, social work

School of Social Sciences and Humanities

33014 University of Tampere, Tampere Finland

Kauko.Outi.E@student.uta.fi

The research was conducted at University of Tampere, School of Social Sciences and Humanities.

This work was supported by Alli Paasikivi Foundation.

The authors report no conflict interest. The authors alone are responsible for the content and the writing of the article.

This article reports the housing pathways of unaccompanied minors and refugee children (hereafter 'UM') in Finland. Of special interest are possible experiences of UM of not belonging as part of the relocations they have faced, and whether UM's descriptions of their housing pathways include experiences of belonging and a sense of home that could be thought to assist with coping. The data consists of qualitative interviews with UM. As a result, for most of them, changes of residence were moderate in number and some of them had no memories of having moved. Some, however, had been relocated frequently. Nevertheless, the meanings attributed by the UM to their housing locations were similar in nature. The most painful experiences of not belonging were particularly associated with the arrival in Finland. The issue of home was ambivalent and had multiple meanings in the course of the housing pathways of the UM. UM highlighted many factors - such as an ordered everyday life - which a receiving country may use to help them in recovering a sense of place, belonging and future safety. Listening UM's experiences offers a number of implications both for the practical work of helping them and the arrangements of the reception and care. 
Keywords: Unaccompanied children, housing pathways, not belonging, home

This article reports a study of unaccompanied minors and refugee children (hereafter ' $U M$ ') ${ }^{\text {ii }}$, a topic that has rarely been studied in Finland. The aim was to analyse the housing pathways of UM: to find out about the children's places of residence before and after their arrival in Finland, the relocations they have undergone in Finland and the meanings attributed by the children to all of these places. At the same time, this is a study of the sequential, multi-local residency of children (Author(s)). Of special interest are possible experiences of UM of not belonging as part of the relocations they have faced, and whether their descriptions of their housing pathways include experiences of belonging and a sense of home that could be thought to assist with coping. Residence and children's views about it form the research focus, since one's place of residence is a tangible part of daily life and can be expected to be an everyday topic of conversation among children. Focus on residence can also shed light on the social, physical and emotional dimensions of place, which are important for daily wellbeing. We assume this to be a useful angle for social work, which often deals with issues of everyday life.

\section{Contextual conditions of migration}

Finland has long been known as a country with low immigration rates. Only in 2014, the number of persons seeking asylum was only 3,651. The global refugee crisis changed the situation, and at the end of 2015, the number of asylum seekers had risen to 32,476 (Sisäministeriö 2016). At the same time, the share of unaccompanied asylum-seeking children grew considerably from previous years, up to 3,024 in 2015 (Maahanmuuttovirasto). In previous years, the mean number had been below two hundred. Most of these children arrive from countries with long-term military conflicts, such as Afghanistan, Iraq and Somalia (Lepola 2012, 8). The children have lost their guardians or been separated from them in their countries of origin or after leaving it. The children's life situation is exceptional in that they have to wait for a decision on their asylum application in a strange country without either their parents or any certainty about the length or outcome of the asylum process. 
In the case of UM, the term 'forced migration' is justified in the sense that the children have no choice over when, how, where or with whom they will start out (Chase and Statham 2013, 224; Helander and Mikkonen 2002, 48-49). In Finland, forced migration continues because of the way reception units for children are managed, rather than as a response to the needs of the children (Lepola 2012, 3). The different stages of the asylum process and the applicant's age cause new changes in the life situation of these children. Initially, the children are often placed in transit units near the capital city, until the Finnish Immigration Service have conducted their asylum interviews. Following this, they are placed in group homes (for those under 16), supported housing units (for those 16-17 years of age) or reception centres (for those who have turned 18 during the process). (Lepola 2012, 8, 80.) On being granted asylum or a residence permit (the latter is granted to the majority) the children are transferred to a municipality, which commonly places the children in a group family home located within its boundariesiii (Euroopan muuttoliikeverkosto 2010, 47). In theory, this will remain their residence until they turn 18 or their family arrives in Finland. However, housing units are set up and closed down according to the numbers of asylum seekers, which may mean that the children need to be relocated.

At the arrival stage, a district court assigns a representative to look after each child's interest (Act on the Reception of People Seeking International Protection, 746/2011, Section 39). The system of representation was set up to create permanence for the child during their sojourn in the country without a guardian; however, when the children are relocated their representative also often changes. (Lepola 2012, 80.) The granting of a permanent residence permit enables the child's family members to apply for residence permit (Aliens Act, 301/2004, Sections 3738). As with the asylum process, the family reunification process also comprises many stages, waiting periods and uncertainty (Mikkonen 2013,22). With the tightening of the legislation on the family reunification of aliens in 2012, the number of unfavourable decisions increased, causing the relationships to representatives intended as temporary and the period of waiting time and time spent in the family group home to lengthen (Lepola 2012, 100). Currently, the statutory conditions for family reunification are being further tightened in Finland. 


\section{Theoretical background}

Most of the existing research on UM has focused on the mental state of the children from the perspective of trauma. The children's situation has typically been characterised through the concepts of loss, uprooting and separation. (e.g. Wernersjö 2012, 495-496.) The accumulating sense of loss is caused by the separation from family, friends and community, the deaths or disappearances of close relatives or friends and a longing for a past life that is remembered as safe. Longing for family members, grieving for their loss or recurring worry over whether they have survived are accompanied by feelings of loneliness, detachment and isolation. (Chase and Statham 2013, 226.) Migration studies have also shed some light on the cycle of departure, journey, arrival and settlement - the dimensions of moves, place and time of UM (see, e.g., Koser 2016). UM are reported to face many transitions, relocations and general uncertainty in environments that are geographically, linguistically and culturally distant from their homes (e.g., Kohli 2011, 313). Lastly, earlier studies have regarded conceptions of home as central, as migration is associated with both leaving the place called home and finding other places that one must learn to make home (Archambault 2012, 38). According to Fox O'Mahony and Sweeney (2010, 291), people will instinctively seek to reinstate a sense of home, regardless of where they are.

The theoretical framework of this study on UM rely on an approach that examines housing pathways and the meanings attributed to the places they include (Clapham 2002, 57-68). In this approach, housing is viewed as individual processes evolving over time, which may include many housing locations and pathways comprising these. It is suggested that the neutral concepts of place of residence, moving and change of residence are close to children's daily life (Andenæs 2012). Thus, by focusing on residence and residential mobility, the dimensions of mundaneness and sense of place, important for daily well-being, are sought.

The theoretical roots of this approach lie in social constructionism: in addition to tangible housing locations, a housing pathway is understood to be importantly constructed by individual meaning-giving, but also in interaction with the structural conditions of life within a framework formed by such things as war, refugee policy and housing policy. 
Clapham, who developed the concept, stresses that a housing pathway is more a metaphor than a theory. It is a metaphor of how a person may have multiple and changing housing situations during their life (ibid). Desmond and Perkins (2015) demonstrated this by asking their interviewees to record all the places in which they had lived or stayed for at least a month over a period of two years. This included staying in someone else's home or an institution or, say, being imprisoned. Parallel to the changes of residence were changes in what persons belonged to a household. A linkage of this sort may have even more important consequences for children's lives than the actual fact of moving. (Ibid.) Indeed, the above factors are studied as meanings given by the UM themselves. Hence, the present study contributes to a growing body of research focusing on the agency and perspectives of UM (Wernersjö 2012, 2014, 2015; Kohli 2011; Sirriyeh 2010, 2013).

The concept of the housing pathway comes close to the idea of sequential, multi-local residency. The background to the latter lies in the study of childhood and spatiality (e.g., Holloway and Valentine 2000), and it provides tools for the study of time, place and movement. Through intervening with the housing arrangements of children, the administrative measures in children's asylum processes, for example, contribute to a process of multi-local living and residency. Children who live multi-locally realise their lives in several physical locations and social environments (Schier 2015).

Beside the concept of the housing pathway, central for us are the concepts of home and the sense of not belonging, which are seen as important in constructing of meanings for housing locations. For UM, the conditions of life in a particular place are important in terms of meanings associated with them (Wernersjö 2014, 48). For the concept of home, a distinction is made between the concepts of housing and home. We consider the former to be a neutral term denoting a place of residence, and a 'home' a term loaded with multiple meanings (compare, e.g., Koser 2016; Wernersjö 2014, 2015; Kohli 2011; Fox O'Mahony and Sweeney 2010). Home is an intersection of place, time and social relationships and also closely connected to an emotional sense of belonging - also having the potential of being a location of oppression and violence. Home is a multidimensional process; it is possible to identify the connections and reverberations of home between past, present and future homes. The meanings of home can change according to time and context. Home is a construction 
involving acts of imagining, creating, changing and moving 'homes'. Home is not limited to a physical place; it can be a memory or a state of mind - a sense of home, such as a sense of security or belonging. A place of residence is not necessarily a home if it does not feel like a home. (e.g., Taylor 2015.)

The sense of not belonging is understood to refer to the experience of being an outsider, a stranger or displaced. Not belonging is understood as related to the concept of loneliness ${ }^{\text {iv }}$ (author). Because of their temporary status (Fox O’Mahony and Sweeney 2010, 291), UM are exposed to these kinds of experiences. Arrival in a new country is accompanied with new experiences, such as unfamiliarity (Kohli 2011, 313) or feeling of being in-between spaces (Sirriyeh 2010,214). A strange place with unfamiliar codes and rules often intensifies the feeling of being a stranger. What is more, others may treat arrivals as strangers. Even after receiving a residence permit a sense of temporariness may continue. Due to potential relocations, UM face the task of adapting to new circumstances while, at the same time, losing the social contacts they have established in their previous places of residence. This makes experiences of loneliness even more likely.

Against this background, this study focuses on the meanings given by UM to changing, sequential places of residence (Clapham 2002). We are especially interested in the potential meanings of the sense of not belonging. In addition to not belonging, however, our interest is also in whether children's descriptions of their housing pathways contain meanings of home, belonging and sense of home - the last-mentioned may be thought to assist with coping. Over time, the status of being a stranger may be overcome, which will bring a sense of being at home and an accepted membership in a social collective (Wernesjö 2014, 48).

\section{Data and analysis}

The data consist of 12 semi-structured interviews with UM (around 15-17 years old). They come from different countries in Africa and Asia. Eight are boys and four girls. In their countries of origin and sex, the interviewees correspond to the majority of UM seeking 
asylum in Finland (Helander and Mikkonen 2002, 11). The interviews were conducted in autumn 2013, at which point the children had been living in Finland for an average of four years.

The interviewees were reached through a family group home and their court-appointed representatives. In addition to the interviews, some observations were carried out in the family group home along with informal chats with the children and the staff. The interviewees were children who had received residence permits in Finland; this choice was made to prevent the children confusing the researcher with the authorities involved in the asylum process (see also Vitus 2010,32) or assume that the interview would affect their asylum decision. Furthermore, these children are in a more stable situation of those still waiting for a decision on their asylum process (e.g., Wernersjö 2014, 32). During the period of waiting, they may be unwilling to talk about such issues as fleeing, returning or adapting (Vitus 2010, 32).

Being interviewed required the consent of not only the child, but also his or her courtappointed representative. The aim was to avoid all manner of pressure when recruiting the interviewees, even though the representatives and the staff at the group family home took an active part in finding interviewees. The children were given information about the study. Some of them consented on condition that the time before their arrival in Finland would not be dealt with. Thus, all the information presented here is based on what the interviewees chose to reveal during the interview and these choice were respected. Every attempt was thus made to observe the principles of voluntariness, consent and trust and ethical symmetry (Strandell 2010, 95-105). The data gathering complied with Finnish ethical instructions (Kuula 2011).

The interviews were conducted privately in each child's housing unit: in the child's own room, where possible, or in another space. At the start of the interview, the child was again informed about the purpose of the study, with stress on the fact that they need not answer every question and that they could terminate the interview at any time. The interview proceeded from dealing with the present moment to the immediate past and only dealt with 
stages before their arrival in Finland if the interviewee wished to speak about these (also Hopkins 2008, 40). The themes selected dealt with housing as both a material and social (interpersonal) environment, daily life and arrival in Finland, and where possible, life before that. Most interviewees spoke Finnish fairly well; only one of the interviewees requested that English should be used. All interviewees consented to the interviews being recorded for later transcription.

During the analysis, a housing pathway was constructed for each child on the basis of the interview: this was a timeline containing the places in which the interviewee mentioned having lived, in chronological order. After this visualisation the housing pathways were compared with each other. On the basis of the interviews, three types of housing pathways were identified; the differences between them were most marked by the number of relocations. In addition, the meanings given by the UM to their places of residence were subjected to close reading, with particular attention to experiences both of not belonging and of the sense of home.

\section{The nature of the children's housing pathways}

The next empirical section portrays, first, the types of housing pathways of UM identified in the interview data. These types should be understood as a product of informants' descriptions: sketchy versions, which may omit some events - perhaps because of forgetfulness or unwillingness of the young persons to illustrate their past. Later, in the second empirical section, the dominant meanings given to their housing locations by UM in the timeline of their housing pathways will be described.

\section{The number of moves}

In the most typical type, the children had moved moderately. They had experienced four moves either across state borders, within the same state or between (in some cases, within) 
housing units. In their country of origin, they had not lived in more than two different locations, and most of them had arrived in Finland directly from their country of origin. In Finland, the children had been obligated to move owing to the normative institutional stages - including changes of housing units - of the asylum process. Moving locations could also be linked to their young age: within the housing units, children in primary school and lower secondary school, for example, occupied different sections. When the interviews were conducted, some of the children had lived in Finland for four years, others for just one year. The latter group had thus had to move more frequently.

Some of the housing pathways formed a type characterised by frequent moves, with minimum of seven housing locations. After leaving their country of origin, the children had lived in one or more countries before coming to Finland. Two interviewees had left their home country with their parents, but were living separated from them at the moment. In Finland, they had typically lived in four housing locations. The reasons they mentioned for moving were their age, receiving a favourable decision on their asylum application or a change in their family relationships. When the interviews were conducted, these interviewees had been living in Finland for at least three years.

For a small number of the children, their current housing location in Finland was the only one they could remember. These interviewees had arrived in Finland at such a young age that they did not remember earlier housing locations or circumstances. 'I can't remember, I was so small at the time', was a typical comment made by these children. One could thus characterise this type as a forgotten past.

In conclusion, the children's housing pathway types contained different numbers of moves. What they were able or willing to remember was also affected by whether they were able identify features of their pathways. Forgetfulness was connected to the very young age of the UM or possibly to unpleasant past experiences. Chase and Statham $(2013,225)$ drew a similar conclusion when studying the experiences of unaccompanied asylum-seeking minors: their journeys to the host country were diverse and unique and sometimes framed by the desire to forget. 


\section{Meanings attributed to housing locations in the timeline of the housing pathways}

The interviewees shared the experience of having migrated to Finland as minors, but they differed from each other to some extent in how fresh their memories were of their country of origin. This variation in the background situation of the interviewees created gaps in their experiences, but did not lead to crucial differences in how they characterised their memories of residency: the dominant experiences were similar in nature. In many cases, the interviewees simply listed the places where they had lived before arriving in Finland, while some associated a great number of meanings with them. Next, we present these meanings in chronological order following the timeline of their housing pathways.

\section{Insecurity, fear and some happiness}

Understandably, life in the country of origin was colored by a conflict, such as a state of war, fear, cramped housing and, for some, even homelessness. In the following extracts the interviewees think back to what life was like in the midst of war:

$\mathrm{R}$ : What sort of places have you lived in?

I: I can't really remember, I was really small then. I do remember that I was living in my own home country, that there were quite a lot of sounds of war all the time. Bombs were exploding, I thought that was really scary. (Girl a)

It' not like that at all for me now as it was back home. I was afraid quite a lot of the time, but I'm not as scared any more like I was before. And I don't have to worry about paying for my schooling. (Boy a)

Life in the country of origin was associated with fears because of a state of war. Life in the country of origin was frequently compared in one way or another to life in Finland. Life in Finland was experienced as safe and more carefree. Another thing that was valued in Finland 
was free schooling, for in the country of origin this was not a universal right based on residence.

The greatest differences between living in the country of origin and Finland were described by a boy who had lived on the streets:

Here, there's never a shortage of food. You can go and eat all sorts of things, but in my home country I could not go on living with my mother. I had to live on the streets. It's pretty difficult. ...I didn't sell anything, I just asked people for money to get food. Sometimes they give me something, sometimes they don't. Terrible. It's really a difficult life. Sometimes you have to steal food in order to eat. (Boy b)

Homelessness in the country of origin provides a stark contrast to life in Finland. This boy was used to life without parenting even in his home country, and living on the streets had taught him to fend for himself. Against this background, the rules of institutional life in Finland were difficult to internalise, despite the better material circumstances.

Apart from negative experiences, interviewees also mentioned some good things about their past lives. One such thing was the presence of their family members in their country of origin (see also the later section Home and Sense of home) and the happiness associated with that earlier life. Another aspect of their past life concerned their material housing conditions: some UM did not necessarily see great differences between the quality of housing in the two countries.

To conclude, when UM attributed meanings to their past housing locations, they commonly compare life in the country of origin to life in Finland and thus employ a rhetorical contrast. This could be understood as a way of presenting their cultural ideals of housing. However, the UM's descriptions contained some contradictions indicating potential diversity in their housing backgrounds (also Wernersjö 2014, 61). 


\section{Sense of not belonging}

Some interviewees had experienced a sense of not belonging or the threat of it before coming to Finland. However, the data show that not belonging was particularly strongly experienced at the stage when they arrived in Finland, as is revealed by the following extract:

When I was in that arrival place in Finland, I couldn't sleep at night. Everything was new for me, country, people, everything. (Boy c)

Everything being new is a good description of the unfamiliarity lying ahead, both the myriad changes and possibly of being treated as a stranger in the new country. In earlier UM studies, arrival in the host country has also been described, for very similar reasons, as a shock (Kohli 2011, 313; Chase and Statham 2013, 225-226).

After arrival, factors causing a sense of not belonging associated with housing units and their locality were many. These included the rules of the housing unit and the sanctions for breaking them (e.g., reduced monthly allowance), lack of care, limited opportunities for leisure activities, not having a room of one's own and the difficulty of finding friends. In particular, the residential workers encountered in Finland intensified the feeling of not belonging, as related by a UM girl:

They ought to try to understand those who are alone, and not just think of themselves. Some adults, they're living, they've grown up with their own family. They don't see how you feel or how you've come all the way to Finland. They don't understand that you might have a difficult situation or you have a problem, because they say that it's not a problem for me, it's your business. Now I wouldn't say to anyone that it's not my business, if someone says that I've got this and this. Listen, even if you can't do anything. (Girl b) 
Because of the perceived lack of understanding and thoughtlessness - unempathetic behaviour - of adult Finns in the reception system and housing units, the interviewee describes her experience of not having been heard or cared about. The sense of not belonging is emphasised by the absence of family (also Chase and Statham 2013, 226).

In the housing location, the sense of not belonging is also associated with the residential workers' rotas which determine who of them are present. These shifts had an effect on both the building of trust and feeling cared-about, which are essential factors in constructing a sense of belonging. One concrete drawback related to caring had to do with food:

Every day they just cook the same food or, like, something that kids don't like. (Boy b)

The interviewee is happy about the fact that there is food in Finland, but he is not satisfied with what is served. At another point during his interview, he mentions that he has no say in what food is served in the housing unit. This was also the case with many other things mentioned by the interviewees, such as leisure activities or having a room of one's own.

Some interviews revealed that the sense of not belonging may also be increased by peers in the residential environment (such as by name-calling). Moreover, receiving a residence permit means relocation and, in the worst case, is associated with losses:

I had a girlfriend there and my girlfriend's family. I mean the family of my girlfriend, they treated me so good. And I was in their home and they liked me, I liked them. But then when (the residence permit was granted) I came here and I lost them. (Boy c)

The extract reveals how institutional practices of relocation lead to the breakup of close social relationships already established in the receiving country. This intensifies the sense of not belonging as regards both relationships and places, making settlement more difficult. Every 
relocation will have its effect on the child's daily life, such as opportunities for social contacts (Lepola 2012, 83).

Finally, experiences of not belonging related to the broader social environment around the housing unit were also described:

I feel like I don't belong in this place at all. When you think about the kind of people that live here, for example. I'm not saying they're all alike, but the sort of way they generally behave here. Personally I've been here for so long that I basically behave in the same way, but somehow it still feels terribly distant, the way people are. I feel that the people here just never get excited about anything. (Girl c)

The extract reveals lack of the emotional dimension of belonging. Although the interviewee can only really remember living in Finland, she has a sense of not belonging to the place and the people living there. Despite the fact that during a long period of living together with Finns she has not only become used to but also internalised their behaviour, this behaviour feels unfamiliar. On the other hand, the interviewee mentions that she has no actual contact with her own culture either, which is another factor explaining the sense of not belonging.

In sum, the sense of not belonging is linked to the unfamiliarity which UM face on arriving in Finland and which continues owing to structural features of the refugee system, such as constant changes in one's place of residence and of the people working and living in these places. Hence, UM encounter many challenges in establishing belonging to someone and somewhere (cf. Kohli 2011, 315).

\section{Home and Sense of home}


Parallel to not belonging, the concept of home was depicted by the interviewees in many different lights. On the one hand, home is a nostalgic memory of the country of origin. A fair number of the interviewees did, however, also see their current housing location as home. For some, home is a chain linking the two homes, or some kind of intermediate space between them.

Many interviewees said that their 'real home' is 'in my own country', whether or not a physical home still existed in the country of origin. In addition to being linked to a place, home is defined through nuclear family relationships, regardless of where the family members were living at that moment. In this sense, the definition of home is fictional:

$\mathrm{R}$ : What do you think of when you hear the word home?

I: My own country.

I: What makes home a home?

I: That you like to live there and you feel safe.

$\mathrm{R}$ : Is it linked to any particular people?

I: Yes.

R: What people do you need, to have a home?

I: Family.

$\mathrm{R}$ : By that you mean parents and siblings?

I: Yes. (Girl a)

The interviewee localizes home in her own country of origin and equates a sense of home with liking to be there and feeling safe, despite earlier in the interview describing having felt fear because of war. Home is also linked to her parents and siblings, despite the fact that later in the interview she says that she will not be living with her parents in the future because she will soon be coming of age and is planning to start a family of her own. However, most interviewees expressed a wish for family reunification and a life with their family, especially with their parents. Some interviewees mentioned that they were in contact (for instance, by phone) with their parents, which was felt to be important. 
Mothers were felt to be particularly important for having a sense of home:

If my mother is not in the home, then it's not a home. I'm just living there, but I don't feel it's home. When I come to this family group home, I'm given help. But I don't feel like it's my own home, so I've got the thought that if my mother isn't with me then there's nothing left any more. (Girl b)

Being the eldest, the girl looked after her younger siblings in her home country after her father had disappeared and her mother had to take up work, but nevertheless in her mind it is the mother's presence that changes a housing location into a home. For this girl and the other UM interviewees, the mother represented an indispensable, close and long-term social relationship which includes caring, comfort and intimacy.

In the best case, however, the people present in the place of residence can promote the sense of home, as is shown by the following extract:

One of the workers. A really nice person. I'll never forget her. I'm always telling her, when you're really old and you've retired, I'll come and visit you. She's just like my mother. She always listens to me. (Girl b)

The interviewee mentions that one of the residential workers is close to her like a mother. The relationship she describes suggest a family-like intimacy (see Sirriyeh 2013, 5, 8). Close social relationships are important for having the possibility to feel at home (Wernersjö 2015, 458). Besides people, one of the interviewees stated that pets could make living and making a home easier, in other words, create a sense of belonging to the housing unit. This notion is also based on familiarity (cf. Wernersjö 2014, 51-52): the interviewee was used to animals in the household in the country of origin. 
Besides having sequential homes in the country of origin and in Finland, the children mentioned the possibility that one could have several homes simultaneously:

R: Where's your home?

I: My home. Well, I've got two homes.

$\mathrm{R}$ : What are they?

I: Here in Finland and in my country of origin. (Boy a)

$\mathrm{R}$ : What do you think, where is your home?

I: Now that was a really difficult question. I'm between two. Either with my mother or here. (Girl c)

In the former extract, there is a second home in the current country and place of residence, in addition to the memory of the home in the country of origin. Though the homes are chronologically sequential, in the mind they are simultaneously present, with the remembered home containing the sense of home. In the latter extract, the girl has parallel homes in Finland, one in the housing unit and another with her mother. The words 'between two' can also be interpreted to mean that she does not feel she belongs sufficiently to either place.

Nevertheless, it is possible to interpret that most of the interviewees experienced a sense of belonging and being at home in Finland at least in some way. Some said that they just liked living in Finland in general or they liked their current place of residence best in Finland. Being granted a residence permit enables the experience that Finland is a more permanent country of residence. The current place of residence is home, at least until further notice: 'This is where, not permanently, but it's a temporary place to stay.' Living in the same place long enough with familiar routines and people equals a sense of home for many (also Wernersjö 2014, 51).

To pull together the ideas in this section, the concept of home is complex, and the UM combined multiple meanings it. On the concrete level, home is a place to live in - in the past, 
at the moment or in the future. The sense of home and belonging includes safety, familiarity and an emotional dimension relating to both the places of residence and the people in those places (see Wernersjö 2014, 50-51; 2015, 454), and comes close to the concept of settlement.

\section{Optimism}

Most of the interviewees planned a future life in Finland. Acquiring a residence permit not only allows them to be and feel safe, but also opens up future horizons. They thought they would construct a future home in the host country at the point when they could decide for themselves where to live. Making a home in Finland is also implied in the interviewees' wish and desire to learn Finnish. The interviews revealed that having a common language is an important factor in making one belong. In addition to Finnish, the interviewees hoped to be able to study new languages and maintain their previous languages, especially their native language. Many had plans to visit their families, although returning to their country of origin to live was only a possibility if the situation there were to calm down.

UM not only cannot choose where they live, but also cannot choose with whom they live. The interviewees who were close to attaining their majority were looking forward to a more independent life in Finland - some also planned to start a family of their own - and the younger ones mostly hoped for a private room in their current housing unit. As a motivation for moving to another locality, many interviewees mentioned familiarity with a (larger) town and the social contacts that it would allow. Some mentioned that what they studied would determine where they would live.

Besides the issue of where and how to live, most interviewees planned to continue studying after compulsory comprehensive school and then work in Finland: 'For me it is important to study to be something when I turn eighteen. And to make my future', as one of them put it. Making a future home in Finland and the desire to succeed educationally and materially in the receiving country (Kohli 2011,319) is emphasizes their agency along with their growing optimism (Wernersjö 2014, 73-74). 


\section{Discussion}

In the above, the idea of the housing pathways of UM has been used to examine their sequential multi-local residency and the meanings they give to their various places of residence. Although the porosity in our small data set some limits to the possibilities of generating thick description of the housing pathways, it was possible to identify that for most of UM, changes of residence were moderate in number and some of them had no memories of having moved. Some, however, had been relocated frequently. The housing pathways identified were the result of a combination of the push factors of the UM's home country, the immigration practices of the host country and the meanings attributed to them by the individual UM. In spite of differences in the interviewees' backgrounds and gaps in their descriptions, the dominant meanings they attributed to their places of residence and relocations during the time line of their housing pathways were similar.

The sense of the places where the interviewees had lived before their arrival in Finland were mainly associated with fear and insecurity, although some positive aspects were also emphasised. The most painful experiences of not belonging were particularly associated with their arrival in Finland: encountering an unfamiliar country, language and culture all on one's own induced in the involuntary immigrant a strong sense of externality (also, e.g., Kohli 2011). Moreover, the UM reception system and migration policy include aspects which do not contribute to a sense of belonging. From a child's perspective, unpredictable and rapid changes of places, even across state borders in the event of refused entry, do not support the building or sustaining of close, long-term relationships (also Wernersjö 2014).

The issue of home was ambivalent and had multiple meanings along the housing pathways of the UM: on the one hand, home was the lost home and family in the country of origin (also Sirriyeh 2010), while on the other hand it was the emerging sense of home in the current place of residence (see Wernersjö 2015), as well as a combination of, or an intermediate space between, the two. The home in the country of origin remains part of the mindset and 
may also be nostalgic to some extent. Upholding a positive image helps with coping. An emphasis on the irreplaceability of the family may be associated with an idealised image of the family, which is strengthened in exile (Stepien 2008). Speaking of one's own family is understandably also linked to hopes of family reunification, which for the majority of the interviewees was still an on-going process with an uncertain outcome. Experiences of gradually making a home in Finland are, however, present and possible, as described by the interviewees. Most of the interviewees said that their current housing unit is like a home (also Wernersjö 2014), despite the lack of social relationships or problems with these (also Helander and Mikkonen 2002). In many respects, the findings reinforce those of previous studies on UM (e.g., Wernersjö 2014), perhaps because of similarities in the structural features of the reception systems.

Nevertheless, the perspective of housing pathways and related feelings of not belonging or of having a sense of home expands the previous debate on the well-being of UM, which has focused on their mental state and trauma. The meanings attributed to housing locations by the $\mathrm{UM}$ as they moved along their housing pathways were coloured by change and uncertainty. An ordered everyday life, continuity and routines can be seen as essential components of ontological safety (Giddens 1991) and a place-sensitive geography of well-being (Fleuret and Atkinson 2007; Chase 2012). In addition to shared meanings attributed by the UM to their housing locations, which resemble those found in the other studies mentioned above housing pathways are individual processes in time with different meanings for individuals. For instance, the interview data include examples of adults (e.g., a residential worker in a family group home) in Finland filling, to some extent, the role of an absent parent(s), an observation that has not been addressed in previous research (Wernersjö 2012).

A number of implications for the practical work of helping UM can be drawn from the findings of this study. The UM themselves revealed many factors which a receiving country may use to help them in recovering a sense of place, belonging and future safety. These include living sufficiently long in the same place to be able to feel a sense of home, since familiarity - an important factor for creating a sense of belonging to place and people (see also Wernersjö 2014, 2015) - may develop over time. The physical stability and safety of the living environment enables UM to focus on everyday things, such as learning the language 
and attending school, as well as hopefulness about the future (also Kohli 2011; Sirriyeh 2010). Similarly, the repetition of daily events, such as daily routines, sleeping, mealtimes and school, brought predictability, familiarity and meaning into their lives (also Chase and Statham 2013). The sense of belonging to a place is aided by crucial interpersonal relationships (Archambault 2012). In the best case, a familiar circle of friends and adults helps to create sense of belonging (see Kohli 2011; Sirriyeh 2010). In this study, the closest relationships were mainly provided by young people of the same age and sex whom the interviewees had encountered along their housing pathways in Finland (see also Wernersjö 2014).

In their housing pathways, in finding a place, and in belonging and making a home, UM are helped by very ordinary and mundane things, which can be implemented and taken into account irrespective of the bureaucratic practices imposed by the reception system. It is important for that adults involved in reception and aid work have a sensitive and humane attitude and to listen to the children (also Kohli 2011). By paying attention to reciprocity and interaction that respect the UM's agency, it is possible to build a relationship that helps create a sense of belonging (see also Sirriyeh 2013) and of home (Kohli 2011). Efforts to decrease the continuous turnover - not only of places of residence - but of the employees in housing units, for example, would increase experiences of trust and caring (cf. Sirriyeh 2013). In addition to care and caring, the support given to friendships and enabling leisure pursuits and studies are factors which UM consider meaningful in their everyday lives (also Wade, Mitchell, and Baylis 2005). Overall, the experiences of UM may and should be listened to, and they should be treated as ordinary human beings with ordinary needs when discussing future arrangements regarding their housing and related care, especially the extent to which their reception and care bestow a sense of belonging and home (also Wernersjö 2015).

\section{References}

Act on the Reception of People Seeking International Protection 746/2011. http://www.finlex.fi/fi/laki/ajantasa/2011/20110746.

Aliens Act 301/2004. http://www.finlex.fi/fi/laki/ajantasa/2004/20040301. 
Andenæs, Agnes. 2012. 'From 'Placement' to 'a Child on the Move': Methodological Strategies to Give Children a More Central Position in Child Welfare Service." Qualitative Social Work 11 (5): 486-501.

Archambault, Josée. 2012. “It Can Be Good There Too': Home and Continuity in Refugee Children's Narratives of Settlement." Children's Geographies 10 (1): 35-48.

Chase, Elaine. 2012. "Security and Subjective Wellbeing: The Experiences of Unaccompanied Young People Seeking Asylum in the UK." Sociology of Health \& Illness 35 (6): $858-872$.

Chase, Elaine, and June Statham. 2013. "Families Left Behind: Unaccompanied Young People Seeking Asylum in the UK.” In Family Troubles? Exploring Changes and Challenges in the Family Lives of Children and Young People, edited by Jane Ribbens McCarthy, CarolAnn Hooper, and Val Gillies, 223-231. Bristol: Policy Press.

Child Welfare Act. http://www.finlex.fi/fi/laki/ajantasa/2007/20070417.

Clapham, David. 2002. "Housing Pathways: A Postmodern Analytical Framework." Housing, Theory and Society 19 (2): 57-68.

Desmond, Matthew, and Kristin L. Perkins. 2015. "Housing and household instability." Urban Affairs Review 1-16. DOI: 10.1177/1078087415589192

Euroopan muuttoliikeverkosto [European Migration Network]. 2010. Yksin maahan tulevien alaikäisten vastaanottoa, palauttamis- sekä kotouttamisjärjestelyjä EU-jäsenmaissa koskeva vertailututkimus [Comparison Study Concerning the Arrangement of Reception, Return and Integration of Unaccompanied Minors in EU countries]. http://www.emn.fi/files/372/EMN_UAM_fi_synteesitutkimus.pdf.

Fleuret, Sebastien, and Sarah Atkinson. 2007. "Wellbeing, Health and Geography: A Critical View and Research Agenda." New Zealand Geographer 63 (2): 106-118.

Forsberg Hannele, Aino Ritala-Koskinen, Leena Autonen-Vaaraniemi, and Outi Kauko. 2014. Lasten monipaikkainen asuminen sosiaalisena ilmiönä ja hyvinvoinnin kysymyksenä [Multi-local Residency of Children as a Social Phenomenon and a Question of Welfare]. Hyvinvointikatsaus 25 (1): 29-35. 
Fox O'Mahony, Lorna, and James A. Sweeney. 2010. "The Exclusion of (Failed) Asylum Seekers from Housing and Home: Towards an Oppositional Discourse." Journal of Law and Society 37 (2): 285-314.

Giddens, Anthony. 1991. Modernity and Self-identity: Self and Society in the Late Modern Age. Cambridge: Polity Press.

Helander, Reetta, and Anna Mikkonen. 2002 Ikävä äitiä... Ilman huoltajaa tulleet pakolaislapset Suomessa [Longing for Mother... Unaccompanied Children in Finland]. Väestöntutkimuslaitoksen katsauksia [Overview of the Family Federation of Finland] E 13/2002. Helsinki: Väestöliitto.

Holloway, Sarah L., and Gill Valentine, eds. 2000. Children's Geographies: Playing, Living, Learning. London \& New York: Routledge.

Hopkins, Peter. 2008. "Ethical Issues in Research with Unaccompanied Asylum-seeking Children." Children's Geographies 6 (1): 37-48.

Kauko, Outi. 2014. Lasten yksinäisyys vanhempien erotessa - näkökulmana lasten kuvaama kuulumattomuus ja siitä selviytyminen [Children’s Loneliness after Parental Divorce: Narratives of Not Belonging and Coping]. Nuorisotutkimus 32 (1): 3-17.

Kohli, Ravi K. S. 2011. "Working to Ensure Safety, Belonging and Success for Unaccompanied Asylum-seeking Children.” Child Abuse Review 20 (5): 311-323.

Koser, Khalid. 2016. "Introduction: Unaccompanied Minors Virtual Issue.” In Virtual Issue: Unaccompanied Minors.

http://www.oxfordjournals.org/our_journals/refuge/unaccompanied\%20minors\%20virtual\%2 0issue-koser-2016.pdf

Kuula, Arja. 2011. Tutkimusetiikka: Aineistojen hankinta, käyttö ja säilytys [Research Ethic: Acquisition, Use and Preservation of Materials]. Tampere: Vastapaino.

Lepola, Outi. 2012. Ei omainen eikä viranomainen - Selvitys ilman huoltajaa Suomeen tulleiden lasten edustajajärjestelmästä [Neither a Relative nor an Authority - Account on the Unaccompanied Children’s Representative System in Finland]. Helsinki: Lastensuojelun keskusliitto. 
Maahanmuuttovirasto [The Finnish Immigration Service]. Statistics on Asylum and Refugees. Minor Unaccompanied Asylum Applicant 2015.

http://www.migri.fi/download/65012_EN_tp-

hakijat_alaikaiset_2015.pdf?db9e77a7eb35d388

Mikkonen, Anna G. 2013. "Myös Suomeen tulleet pakolaislapset ja -nuoret kaipaavat ja tarvitsevat perhettään" [Also Unaccompanied Asylum-seeking Children in Finland Need and are missing their Families]. Siirtolaisuus - Migration 40: Supplement, 22-33.

Schier, Michaela. 2015. "Post-separation Families: Spatial Mobilities and the Need to Manage Multi-local Everyday Life.” In Spatial Mobility, Migration, and Living Arrangements, edited by Can M. Aybek, Johannes Huinink, and Raya Muttarak, 205-224. Cham: Springer.

Sirriyeh, Ala. 2010. "Home Journeys: Im/mobilities in Young Refugee and Asylum-seeking Women’s Negotiations of Home." Childhood 17 (2): 213-227.

Sirriyeh, Ala. 2013. "Hosting Strangers: Hospitality and Family Practices in Fostering Unaccompanied Refugee Young People.” Child \& Family Social Work 18 (1): 5-14.

Sisäministeriö [Ministry of the Interior]. 2016. Turvapaikanhakijoita saapui viime vuonna ennätysmäärä [Rapid Increase in the Number of Asylum Seekers]. http://www.intermin.fi/fi/maahanmuutto/turvapaikanhakijat.

Stepien, Anna. 2008. "The Dream of the Family: Muslim Migrants in Austria." In The Family in Question. Immigrant and Ethnic Minorities in Multicultural Europe, edited by Ralph Grillo, 165-185. Amsterdam: University Press.

Strandell, Harriet. 2010. “Etnografinen Kenttätyö: lasten kohtaamisen eettisiä ulottuvuuksia [Ethnographic Field Work: Ethical Dimensions of Children’s Encounter]”. In Lasten ja nuorten tutkimuksen etiikka [Research Ethics of Children and Youth], edited by Hanna Lagström, Tarja Pösö, Niina Rutanen, and Kaisa Vehkalahti, 92-112. Helsinki: Nuorisotutkimusseura.

Taylor, Helen. 2015. Refugees and the Meaning of Home: Cypriot Narratives of Loss, Longing and Daily Life in London. London: Palgrave Mcmillan. 
Vitus, Kathrine. 2010. "Waiting Time: The De-subjectification of Children in Danish Asylum Centres." Childhood 17 (1): 26-42.

Wade, Jim, Fiona Mitchell, and Graeme Baylis. 2005. Unaccompanied Asylum seeking

Children: The Response of Social Work Services. London: British Association for Adoption and Fostering.

Wernesjö, Ulrika. 2012. "Unaccompanied Asylum-seeking Children: Whose Perspective?" Childhood 19 (4): 495-507.

Wernersjö, Ulrika. 2014. Conditional Belonging: Listening to Unaccompanied Young Refugees'Voices. Uppsala: Acta Universitatis Upsaliensis.

Wernersjö, Ulrika. 2015. "Landing in a Rural Village: Home and Belonging from the Perspectives of Unaccompanied Young Refugees." Identities 22 (4): 451-467.

\footnotetext{
${ }^{i}$ Outi Kauko was the primary writer of the paper. Her supervisor, professor Hannele Forsberg participated in the whole process of preparing and finishing the manuscript. Her main role was to support and strengthen the coherence of the paper.

ii We use the term unaccompanied minors and the abbreviation UM as the interviewees are children who arrived in Finland as unaccompanied asylum-seeking minors and have been granted a residence permit at some point on their housing pathway, regardless of the grounds for the decision (e.g., refugee status, humanitarian protection) (cf. Wernersjö 2014, 11-12).

iii Group homes and group family homes are not child welfare units. Nevertheless, Section 60 of the Child Welfare Act contains provisions for the qualifications and number of personnel working in them.

iv An interest in children's accounts of loneliness on housing pathways is the primary focus, as the article is part of the first writer's thesis on the loneliness of children in different family transitions.
} 